journals in bringing titles to the notice of readers. It would also seem that the $B T I$ is considerably quicker than its American equivalent; its approximate mean date of publication is 7 weeks in comparison with $A S T I$ 's 11 weeks.

Mr E. J. Coates, editor of BTI, said this week that the time lag was certainly no worse today; if anything, it was better. In fact, this week's issue of the $B T I$ makes use of new computer techniques for the first time. If all goes well, the time lag should soon decrease still further. The assembly and generation of all the necessary cross-references and the print-out of the authority file, previously done manually, are now done by a KDF9 computer at the Newcastle upon Tyne Computing Laboratory under the direction of Professor E. S. Page. Punched tape is prepared in London and then sent to Newcastle for processing. At the moment no attempt is being made to computerize the indexing process. The automation of much of the routine work will, however, allow more time for more efficient and speedier indexing.

\section{Defence Research}

\section{from our Parliamentary Correspondent}

Where should defence research be done? The Select Committee on Science and Technology, investigating the British defence research effort, has heard various versions. The most recent, from the Institution of Professional Civil Servants, was perhaps predictable; it said that the place for defence research was in the defence establishments. "Experience shows that research contracts let to industry and the universities have a limited value, and that they must be closely supervised by scientists from the sponsoring establishment . . . contract research has been extensively used in the United States, but because of the need to provide organizations to co-ordinate and control research effort, there has been a move back to the provision of more 'in house' research." But this was not dogma, Mr William McCall, general secretary of the institution, assured the committee - "It's just a question of where the work can be best done".

Mr Robert Howarth, for the committee, said that the Electronic Engineering Association had taken the opposite view. The fact that the defence establishments were diversifying their activities into the civil field surely suggested that there was not enough defence work to do. Mr McCall said that because the capital investment in public laboratories had already been made, there was little sense in not using them. The fact that there had been a poor return on the investment was a failure of exploitation, not of research and development, he said. But a shake-out of the govern. ment laboratories could only have a small effect on the rate of exploitation.

Within the establishments, the witnesses said that there should be more "special merit promotions", by means of which people can be promoted without having to be burdened with administrative work. And in the Civil Service itself, there should be more permanent secretaries who were scientists. There was a dearth of people with scientific qualifications in the highest posts. The only ministry which got a pat on the back was the Ministry of Transport, where the whole organization has been changed, giving scientists more of a chance to influence policy.

\section{Parliament in Britain}

\section{Concorde}

Mr Anthony Wedgwood Benn, Minister of Technology, gave some information about the Concorde airliner. In the early years, Concorde would be able to carry 20,000 lb. from Paris to New York in critical summer conditions, but later it would be possible to increase this to $25,000 \mathrm{lb}$., thanks to better engines. Mr Benn declined to say how many Concordes he was expecting would be sold, but hoped that the delay to the Boeing SST would mean that the market would go up quite considerably. Conservative members made some misguided interjections-Mr Boyd-Carpenter, for example, suggested that the British prototype of Concorde should be allowed to fly first, because "British technology and engineering had again shown themselves to be superior to those of France, and deserved the publicity that would accrue from making the first flight". Mr Benn was diplomatic-both must fly as soon as possible, he said. The cost price would be such as to get back a proportion of the cost of research and development, though "obviously not the whole of that cost". (Oral answer, May 6.)

\section{Oceanography}

Mr Gerry Fowler, Minister of State at the Ministry of Technology, said that he had no plans to set up a national agency to deal with the exploitation of the oceans. But studies of the best way of handling marine science and technology were now in hand. A national agency would involve substantial re-arrangement of ministerial responsibility without compensating advantages. The committee on oceanography under the Vice-President in the United States probably had more apparent than real cohesion, he thought, since it had no overall financial or executive control of the US national research programme. He would not agree to produce a White Paper on the Government's intentions in oceanography. (Oral answers, May 6.)

\section{Nuclear Power}

Mr Ray Gunter, Minister of Power, said that he was considering the possibility of publishing a short White Paper which would discuss the siting of nuclear power stations. Mr Arthur Palmer had asked that the advice of the Nuclear Safety Advisory Committee be published-the committee has said that it is now safe to site nuclear stations much closer to cities. (Written answer, May 7.)

\section{Launchers}

THere were a number of questions about the British decision to withdraw from the European Launcher Development Organization. Mr Benn said that ELDO had estimated a cost per launch vehicle of $£ 7$ million, assuming a production run of five, and launches at the rate of three a year. Since only one order was so far discernible (two launchers for the Franco-German Symphonie), no estimate based on a production run of twenty had been made. But it would be unlikely to reduce the cost by more than 10 per cent. He gave some estimates of the cost of United States launchersthe Atlas/Agena would cost $\$ 9-10$ million a launch, while the Atlas/Centaur would cost \$14-15 million. More appropriate launchers to put a communication satellite into a geostationary orbit would be the Thor Delta, at about $\$ 5$ million, and the Titan 111 B/Agena, at about $\$ 10$ million. (Written answer, May 6. ) 